\title{
ЛАМАЮЧИ СТЕРЕОТИПИ
}

Стаття присвячена завідувачу кафедри фінансово-економічної безпеки, обліку та оподаткування Української академії друкарства, доктору економічних наук, професору А. М. Штангрету, якому у цьому році виповнилося сорок років.

Науковці - це окрема спільнота людей, яких єднає одна загальна мета - отримання знань про явища навколишнього світу. Окрім загальної мети, науковців об'єднують притаманні їм риси, що сформувались під впливом особливостей наукового життя i шліфуються в процесі всієї їх наукової діяльності. Та попри наявність спільних рис, спільнота науковців досить строката, ця різноманітність $€$ наслідком не відмінності між галузями знань і методами дослідження, а індивідуальності кожного науковця, його особистісних якостей, що відповідають чи навпаки не вписуються у певні стереотипи.

Зазвичай, випадкові люди в науці - рідкість, адже науковцями стають за покликом душі, а не за збігом обставин. От лише шлях до науки у кожного свій. Що стосується мого шляху в науку, то він розпочався досить пізно, коли вже багато що побачено й спробувано. Мені пощастило зустріти людину, яка ламає стереотипи щодо сутності вченого.

Хочу розповісти про свого наукового керівника Андрія Михайловича Штангрета - завідувача кафедри фінансово-економічної безпеки, обліку та оподаткування Української академії друкарства, де маю честь працювати під його керівництвом.

(C) $2017 p$.
Перший стереотип: значний науковий досвід - наслідок лише багаторічної праці

Пам'ятаю своє знайомство з Андрієм Михайловичем, яке відбулось на його робочому місці. Йдучи на зустріч зі своїм майбутнім науковим керівником, я не багато знала власне про нього, тому була дуже здивована, коли замість поважного пана мене зустрів досить молодий чоловік, з відкритим обличчям і трохи стриманою посмішкою. Розмова пройшла конструктивно і Андрій Михайлович погодився стати моїм науковим керівником, попередивши, що результат буде залежати від того, наскільки ефективно я зможу опрацювати обрану тему наукового дослідження.

Уже згодом, коли ми почали активно співпрацювати, я зрозуміла, як йому вдавалося встигати робити так багато - усі його наукові і професійні досягнення $\epsilon$ результатом раціонального використання великої енергії. Окрім того, Андрій Михайлович володіє цінною здатністю впорядковувати не лише свою роботу, а й усі процеси, в яких він бере участь, чим, до речі, значно полегшує роботу іншим учасникам справи. Результатом поєднання енергії, природнього розуму і цілеспрямованості став значний перелік його наукових і професійних здобутків. 
Андрій Михайлович є автором і співавтором понад двохсот наукових та навчально-методичних праць; він очолює кафедру фінансово-економічної безпеки, обліку і оподаткування, де під його началом дружньо та плідно працює колектив науковців і педагогів; за його керівництвом та безпосередньої участі виконуються держбюджетні та госпдоговірні теми. Андрій Михайлович бере активну участь у роботі спеціалізованих вчених рад із захисту дисертаційних робіт, є членом редколегій фахових видань. Під його керівництвом виконано та успішно захищено дисертаційні роботи на здобуття наукового ступеня кандидата економічних наук.

3 Українською академією друкарства, Андрій Михайлович поєднав своє життя ще у 1994 р., коли вступив на факультет економіки та організації книжкової справи. Потім була аспірантура і початок нового етапу - науково-педагогічна діяльність. Після успішного захисту 2003-го р. в Інституті регіональних досліджень НАН України дисертаційної роботи на здобуття наукового ступеня кандидата економічних наук на тему «Попередження та уникнення банкрутства промислових підприємств (на прикладі підприємств поліграфічної промисловості)» - науковий керівник академік НАН України М. І. Долішній, продовжилося становлення молодого вченого і ефективного професіонала.

Андрій Михайлович постійно удосконалював свій науковий і професійний рівень, ось основні етапи зростання: протягом 2005-2007 рр. - отримував сти- пендію Кабінету Міністрів України для молодих учених; 2012-го р. в Національному авіаційному університеті захистив дисертаційну роботу «Методологія управління економічною безпекою підприємств авіаційної галузі на принципах економіки знань» на здобуття наукового ступеня доктора економічних наук науковий консультант професор О. В. Ареф'єва; з 2013 р. - завідувач кафедри.

Напрацювання Андрія Михайловича з економічної безпеки підприємств, зокрема, у сфері управління антикризовою діяльністю, знайшли своє відображення у низці монографій, підручників та навчальних посібників, які у систематизованому, зручному для сприймання форматі, слугують базою для проведення навчального процесу.

Відомо, що результат щоденної кропіткої праці на науковій ниві залежить від трьох складових: природнього розуму, працьовитості та потенціалу. У випадку з Андрієм Михайловичем усі вони працюють на результат.

Другий стереотип: хороший науковець не завжди хороший педагог

Пам'ятаю свою першу статтю, написану під керівництвом Андрія Михайловича, точніше сам процес іï написання. Не знаю, де мій керівник брав сили і терпіння пояснювати, що наукова стаття має бути: по-перше, науковою, по-друге, чітко розкривати суть поставлених завдань. Він учив структурувати свої думки з досліджуваної теми, приділяти увагу кожній важливій деталі, і це в той час, коли підготовка ним 
своєї докторської дисертації вже була на завершальній стадії. Лише зараз, захистивши дисертацію, можу уявити, який величезний обсяг роботи в той час потрібно було виконати Андрію Михайловичу. Та я не бачила його втомленим чи роздратованим. Більше того, він завжди знаходив потрібні слова підтримки, що додавали мені впевненості в собі. Підтримка була у всьому: і перед першим виступом на конференції, коли почала проводити заняття із студентами, навчаючись в аспірантурі, та найбільше - в процесі написання дисертаційної роботи. Кожен підрозділ не просто був прочитаний, він був проаналізований, прокоментований і виправлений. Рекомендації, які я отримала під час написання дисертації, використовую дотепер.

Незважаючи на те, що мій керівник молодший за мене, я багато чому навчилася в нього не лише в професійному плані, а й у життєвому. Зокрема, завдячую Андрію Михайловичу за вміння: дивитися на речі з різних ракурсів, а також за стратегічне мислення.

Яким би великим не було прагнення досягти результатів в науковому світі, воно ніколи не може завадити поділитися своїм досвідом з іншими, в чому і полягає справжнє покликання педагога.

Третій стереотип: кар'єрне зростання породжує дистанцію

Знайома з Андрієм Михайловичем 32011 р., працюю під його керівництвом з 2013 р. Термін ніби то й невеликий, але достатній для того, щоб зрозу- міти, яка людина поряд із тобою. Він повністю змінив моє уявлення про те, що успішні люди, зокрема у професійній сфері, автоматично дистанціюються від інших.

Будучи завідувачем кафедри, професором, доктором наук, Андрій Михайлович залишається таким же щирим і відкритим до всіх, починаючи з колег і закінчуючи студентами. Завжди можна розраховувати на його допомогу і пораду, як з професійних, так і з життєвих питань.

Добре пам'ятаю захист своєї дисертації в Харкові. Напередодні і в день захисту Андрій Михайлович підтримував і заспокоював мене, координував і контролював всі організаційні моменти, пов'язані із захистом, створюючи самою своєю присутністю атмосферу впевненості в успіху. Зосереджена на власному хвилюванні і звикла до того, що мій керівник завжди витриманий і спокійний, я лише після захисту, сидячи у вагоні потягу, що віз нас до Львова, зрозуміла скільки енергії витратив на захист моєї дисертації Андрій Михайлович.

Переконана в тому, що кожен, хто так чи інакше співпрацював з Андрієм Михайловичем погодиться із тим, що мій керівник людина відповідальна. Будучи від природи людиною доброю, Андрій Михайлович може викликати хибне враження про себе, як про людину м'яку. Хочу запевнити - це зовсім не так. За видимої м'якості він завжди демонструє чітку позицію, як в науковому, так і в організаційному плані, що зазвичай ніяк не відображається на його ставленні до конкретних людей. 
Особливою рисою мого керівника є здатність виокремлювати по-справжньому важливі речі. Найважливіше в його житті це кохана дружина і троє діточок. Саме заради них він і працює. А здатність подивитися на проблему зі сторони дає можливість вирішувати завдання ефективно і швидко, заощаджуючи час для нових справ.

Нині ми часто чуємо про формулу успіху. Вона багато в чому залежить від того, що вважати

успіхом. Андрій Михайлович вважає, що успішна людина та, яка здатна прожити кожен день наповнено, ставити цілі і досягати їх, щиро радіючи досягненням і гідно долаючи перешкоди.

Завдячую долі, що звела мене з людиною рідкісної душевної організації, талановитим науковцем і керівником. Андрію Михайловичу, в свою чергу, хочу побажати, аби на своєму шляху він зустрічав лише по-справжньому гідних і хороших людей!

О. В. Халіна, к.е.н., асистент, УАД 